\title{
Correction to: International Journal of Artificial Intelligence in Education , Volume 29, Number 4, December 2019
}

\author{
Springer US, New York $^{1}$
}

Published online: 13 January 2020

(C) International Artificial Intelligence in Education Society 2020

\section{Correction to: Int J Artif Intell Educ \\ https://doi.org/10.1007/s40593-019-00181-3 \\ https://doi.org/10.1007/s40593-019-00183-1 \\ https://doi.org/10.1007/s40593-019-00184-0 \\ https://doi.org/10.1007/s40593-019-00185-z \\ https://doi.org/10.1007/s40593-019-00187-x}

In this issue, the citation information on the opening page of each article HTML was updated to read "International Journal of Artificial Intelligence in Education December 2019...," not "International Journal of Artificial Intelligence in Education December 2000..."

Springer regrets this error.

\footnotetext{
The online version of the original articles can be found at https://doi.org/10.1007/s40593-019-00181-3, https://doi.org/10.1007/s40593-019-00183-1, https://doi.org/10.1007/s40593-019-00184-0, https://doi. org/10.1007/s40593-019-00185-Z and https://doi.org/10.1007/s40593-019-00187-x
}

Springer US, New York

robert.darnowsky@springer.com

1 New York, USA 